\title{
Toward Dynamic-Based Classification of SMEs
}

\author{
Shaike Marom ${ }^{1}$ \\ ${ }^{1}$ Zefat College, Zefat, Israel \\ Correspondence: Shaike Marom, Zefat College, Zefat 1320611, Israel. \\ Received: February 8, 2021 \\ Accepted: March 26, $2021 \quad$ Online Published: April 1, 2021 \\ doi:10.5430/ijba.v12n3p25 \\ URL: https://doi.org/10.5430/ijba.v12n3p25
}

\begin{abstract}
Small and Medium-size Enterprises have been recognized worldwide for their contribution to the economy, employment and new job creation. Given the importance of small businesses to the economy, policymakers have put efforts in helping to boost small businesses by allocating incentives and support programs to those small businesses with high growth potential; rather than to the small business sector as a whole. However, common size-based classifications of small businesses capture the attributes of the business at a certain point in time, and thus, cannot identify those firms that are likely to grow. This paper offers a dynamic classification to help in identifying pro-growth small and medium-size enterprises, based on past and forward-looking indicators. Such dynamic classification could better serve public policy makers in a more precise allocation of scarce resources toward those small businesses with the highest likelihood to contribute to economic stability and growth.
\end{abstract}

Keywords: small business, small and medium-size enterprises, SME, pro-growth, innovation, public policy

\section{Introduction}

The sector of Small and Medium-size Enterprises (SMEs) is a significant contributor to economies worldwide in terms of share, stability and growth, innovation, new job generation, and social cohesion (Ayyagari et al., 2007; Fadahunsi, 2012; Gamidullaeva et al., 2020; Holmes \& Gibson, 2001; Morrison et al., 2003; Nooteboom, 1988). For example, in the U.S.A., small businesses make up $99.8 \%$ of U.S. employer firms, $47.1 \%$ of private-sector employment, $64 \%$ of net new private-sector jobs, and 33\% of exporting value (Small Business Administration, 2020). Moreover, SMEs have been reported to have a significant importance in supporting recovery during economic recession, as has been the case for the last several years (Ayyagari et al., 2007; Fadahunsi, 2012).

Its capacity to generate new jobs and thus reduce unemployment, as well to enhance economic growth are particularly important attributes of the small business sector arising (a) out of its capacity (Mason \& Brown, 2013; Morrison et al., 2003; Stenholm, 2011), (b) through its productivity (Mason et al., 2009), (c) from its innovation (Coad, 2009; Mason et al., 2009), (d) from its exports and its spill-over effects that are beneficial to other firms (Mason et al., 2009). However, there is growing empirical evidence that a relatively small proportion of small businesses, namely, those that are showing growth over time, are contributing to job creation (Birch, 1987; Burns \& Dewhurst, 1996; Chege \& Wang, 2020; Glancey, 1998; Stanworth \& Curran, 1976; Yazdanfar \& Ohman, 2018) and to substantial economic growth (Birch et al., 1997; Gamidullaeva et al., 2020; Kirchhoff, 1994; Storey, 2016; Westhead \& Cowling, 1995), rather than the entire sector of small business (Acs, 2008; Birch, 1987; Burns \& Dewhurst, 1996; Glancey, 1998; Henrekson \& Johansson, 2010).

Consequently, policymakers are increasingly interested in providing incentives and support programs for those small businesses with growth potential rather than to the small business sector as a whole (Morrison et al., 2003; Nakku et al., 2020). Appropriate targeting of those small businesses with a pro-growth orientation is particularly critical for policymakers in order to apply finite resources effectively (Bridge et al., 1998; Morrison et al., 2003; Peter et al., 2018; Stenholm, 2011). Common size classification, however, of small business cannot effectively identify pro-growth firms, which are heterogeneous in nature (Bannier \& Zahn, 2014; Mason \& Brown, 2013). Attempts to address sub-groups, such as high-tech entrepreneurships, have proved ineffective because of the high failure rate in this sector as well (Mason \& Brown, 2013; Shane, 2008). Shane (2008: 6) asserted: 'Start-ups create far fewer jobs and generate a lot less economic growth than most people think. ... Making policy decisions on the basis of myths about the impact of start-ups leads to a lot of wasted resources and bad incentives.'; and also: 'Policy makers often think that creating more start-up companies will transform depressed economic regions, generate innovation, and 
create jobs. This belief is flawed because the typical start-up is not innovative, creates few jobs, and generates little wealth' (Shane, 2009). Thus, there is a need for a different type of classification, one that can provide a reliable indication of the growth trends of small businesses.

This article addresses the need for an effective means to identify and target pro-growth firms by proposing a new dynamic-based classification of SMEs. The paper starts with a review on current common classification and its drawbacks. It then goes on to develop a dynamic-based classification, and concludes with discussion about the potential use and benefits of the suggested approach.

\section{Literature Review}

\subsection{Review of SME Classification}

Much effort has been invested in creating accurate and practical definitions and classifications for small businesses (Congressional Research Service, 2020; Holmes \& Gibson, 2001; Sen, 2011; Storey, 2016). Most efforts have taken place under the initiative of government and public institutions, which have been the prime users of such classification for the purpose of targeting particular businesses for legislation and support programs (Sen, 2011). Committees have been set up to investigate the issue, working together with experts from academia. The end result has been a proliferation of definitions in different countries that tend to share significant commonalities (Ayyagari et al., 2007; Berisha \& Pula, 2015; Sen, 2011).

A common starting point for definitions has been the qualitative characteristics of small businesses (Meredith, 1992; Storey, 2016). First, in small businesses most of the managerial duties and decision making is done by few people, typically one or two, often the owners. The process of management and decision making is not carried out through formal procedure, but rather through idiosyncratic conduct of the owners (Holmes \& Gibson, 2001; Murphy, 1996; Sen, 2011). Another attribute is that most of the working capital is contributed by owners themselves (Murphy, 1996). Such firms are not independent subsidiaries and their equity is not publicly traded. In addition, and by their nature, small businesses capture but a small share of the market in which they are operating (Holmes \& Gibson, 2001; Kersten et al., 2017; Sen, 2011). Most of the qualitative attributes of small businesses, such as management structure, are not embedded in the core of their classification by government and public institutions, as they are difficult to gauge and codify.

Given the difficulties of using qualitative measures, classifications of small businesses tend to rely on quantitative measures. Most of those classifications use two measures of size: the number of employees and a financial indicator such as annual sales (Ayyagari et al., 2007; Baker et al., 2021; Holmes \& Gibson, 2001; Lukacs, 2005; Storey, 2016). For example, the United States Small Business Administration (SBA) has established a size standard for small business, depending on industry, which is usually stated in terms of numbers of employees or average annual receipts. Sales thresholds range from under US $\$ 1 \mathrm{~m}$ to US $\$ 35.5 \mathrm{~m}$, with US $\$ 7 \mathrm{~m}$ the most common benchmark, and employee number thresholds range from 50 to 1500 employees, with 500 employees the most common benchmark (SBA, 2019). Likewise, the new definition of the SMEs in the European Union is based on number of employees, and either turnover or balance sheet total, divided into three categories - Micro, Small, and Medium-size. Cutoff numbers are: for Micro business 10 employees and $€ 2 \mathrm{~m}$ turnover, for Small business 50 employees and $€ 10 \mathrm{~m}$ turnover, and for Medium-size business 250 employees and $€ 50 \mathrm{~m}$ turnover (European Commission, 2020).

Although size-based classifications are highly reliable and are good in identifying small businesses, as well as administrative issues such as tax and government procurement participation policy; they do not capture change-over-time information, such as growth and job creation (Davis et al., 1996). Thus, size-based classification ineffectively serves policymakers and researchers in distinguishing between businesses that may not be alike in growth potential, even though they fall within the same size category (Morrison et al., 2003; Schwartz \& Malach-Pines, 2007). Aiming to overcome the limitations of static size-based classification, a dynamic classification is proposed.

\subsection{Dynamic Classification of SMEs}

A dynamic classification provides information regarding a firm's growth trends. As such, dynamic classifications can distinguish between firms based on their growth trend, even though those firms may be of the same contemporaneous size, and would not, therefore, be distinguished by a size-based static classification as illustrated in Figure 1 .

The information about growth trends can be collected based on two different conceptual frameworks: past looking and forward-looking indicators. First, past data, which is concrete and tangible by nature, can inform about the growth experienced in a previous period. Second, several forward-looking indicators, such as owners' intentions and 
level of innovation, can be used to predict a future growth trend. These possibilities are discussed below.
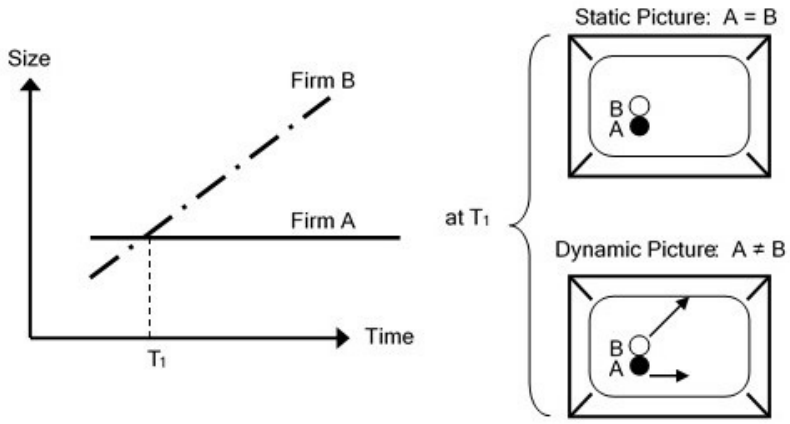

Figure 1. The different results from dynamic and static classification

\subsubsection{Dynamic Classification Based on Past Data}

Dynamic classification can be based on a firm's past growth data. Existing data bases for SMEs include size information in the form of annual sales and the number of employees. Normally, this data is available not only for the current year, but for prior years as well and possibly back to the date of the firm's creation. This data is factual and, therefore, tangible data. Size data in terms of employees and sales can serve to provide the past growth profile of a business. Calculation can include a growth index based on the change in number of employees, a second growth index based on change in sales, and a weighted index based on the two, to improve the robustness of the measure.

There is not a consensus within the literature on the validity of past growth as a predictor for future growth, with studies having different conclusions (Coad et al., 2018; Daunfeldt \& Halvarsson, 2015). Research for the UK (Singh \& Whittington, 1968) and for small businesses in Germany (Wagner, 1992) found that those firms growing faster in one period of time were more likely than others to have an above-average growth rate in subsequent periods; while Coad (2009), covering more than 20 studies, concludes that the overall evidence on serial correlation of growth rates, both positive and negative, is mixed. Some studies (Coad, 2007; Coad et al., 2014; Li \& Rama, 2015; Parker et al., 2010) found mild auto-correlation in firms' growth rate; however, these studies explored particularly high-growth firms (i.e., 'gazelles'). Considering the fact that Gazelles are estimated at around 4\% of the SME sector (Acs, 2008; Birch et al., 1994; Boston, 2011; Daunfeldt \& Halvarsson, 2015; Fritsch \& Wyrwich, 2017); these conclusions about extreme-growth firms and their erratic growth patterns should not taken to represent the entire sector. Moreover, it is commonly accepted that growth pattern is not random as implied by Gibrat's Law. For example, Parker et al. (2010) concludes that: 'Gibrat's Law of random firm growth processes does not generally hold', and Coad (2007) asserts: 'Our results also have implications for Gibrat's Law. On the basis of our findings, this "law" would be rejected because, in many cases, growth rates in consecutive years are not independent'.

Additional problem with tangible dynamic classification would arise when data may not be available regarding previous size characteristics of the business, especially if this is a newly created business. Therefore, the dynamic classification should include an additional element that is forward looking, as described in the next section.

\subsubsection{Dynamic Classification Based on Future Growth Indicators}

Past research has identified several relevant determinants of future growth including owner intentions, characteristics and experience, firm age and sector, level of innovation, excess to financial resources and external advice, and external opportunities (Asa \& Prasad, 2014; Coad et al., 2018; Fadahunsi, 2012; Hansen \& Hamilton, 2011; Lambert, 2018; Morais et al., 2021; Morrison et al., 2003). Level of innovation has been chosen here, as studies have shown that it can serve as a good predictor of growth, as well as being measurable through several methodologies (Ahlstrom, 2010; Qian \& Li, 2003; Verhees \& Meulenberg, 2004; Wolff \& Pett, 2006; Wong et al., 2005). Being indicator of growth, innovation can be used to construct a forward-looking dynamic classification.

\subsection{Innovation and Growth}

Innovation in businesses has been linked to economic growth in the theoretical and empirical literature (Ahlstrom, 2010; Christensen et al., 20118; Hansen \& Hamilton, 2011; Lian et al., 2011; Wong et al., 2005). Theoretically, the foundation for such linkage was established by the work of Schumpeter (1911). Accordingly, innovation drives a 
process of 'creative destruction' creating opportunities for economic growth of which entrepreneurs can make use (Schumpeter, 1942). Additional conceptual models linking innovation and economic growth have emphasized the role of knowledge as well as knowledge spillovers as drivers of economic growth (Aghion \& Howitt, 1992; Grossman \& Helpman, 1991; Than et al., 2019). Furthermore, empirical research has provided evidence in support of the notion that innovation is a driver of economic growth (Barbero et al., 2011; Coe \& Helpman, 1995; Engelbrecht, 1997; Koryak et al., 2015; Verhees \& Meulenberg, 2004; Wolff \& Pett, 2006). Wiklund et al. (2009) have shown that innovativeness of entrepreneurial businesses has a positive effect on their growth, as opposed to owning a small business for a living (Thurik \& Wennekers, 2004).

Several mechanisms have been identified linking innovation with the growth of small businesses, including product and process innovation (Ahlstrom, 2010; Qian \& Li, 2003; Verhees \& Meulenberg, 2004; Wolff \& Pett, 2006; Shirmohammadi et al., 2020). Small businesses can use innovation to generate improved products as well as new products. Such use will provide them with a competitive advantage over other firms in the industry, attracting more customers, increasing market share, price premium, as well as open new markets for the business leading to sales growth (Demir et al., 2017; Iansiti, 1995; Romano, 1990; Wolff \& Pett, 2006; Zahra \& Nielsen, 2002). Small firms' growth associated with product innovation has also been manifested through employment growth (Freel \& Robson, 2004). This mechanism is particularly evident and strong with regard to technological innovation that can bring exceptional economic growth and that can be sustained over longer periods (Ahlstrom, 2010; Helpman, 2010; Landes et al., 2010).

Process innovation is another mediator that positively links small business innovation with growth (Qian \& Li, 2003; Wolff \& Pett, 2006). Process innovation can reduce the level of resources required for the transformation process of the firm. This in turn will facilitate more effective use of resources and reduced size, leading to increased productivity that drives growth (Helpman, 2010; Wolff \& Pett, 2006). Process innovation is particularly valuable for small businesses as it can serve to compensate for the limited resources that are available to them (Buckley \& Mirza, 1997; Qian \& Li, 2003).

The impact of innovation on growth can be particularly effective through disruptive innovations that have new value propositions for customers and create new markets (Ahlstrom, 2010; Christensen, 1997; Christensen \& Raynor, 2003). According to Christensen (1997) disruptive innovation '.. describes a process by which a product or service takes root initially in simple applications at the bottom of a market and then relentlessly moves up market, eventually displacing established competitors.' Growth that is driven by disruptive innovation is more powerful in terms of competitiveness, profits and the firm's ability to sustain that growth over longer periods (Christensen \& Raynor, 2003; Foster \& Kaplan, 2001).

Innovation has been measured in different ways (Qian \& Li, 2003; Verhees \& Meulenberg, 2004; Wolff \& Pett, 2006). Level of innovation can be measured by input and/or output (Coad \& Rao, 2008). Coad and Rao (2008) suggested that input refers to the level of R\&D spending which 'can be considered as an input into the production of inventions'; while number of patents can serve as a measure of innovativeness output, although not all inventions and innovations are patented. The way innovation is measured should be adjusted to the specific sector to compensate for cases where innovation is not as much related to formal R\&D, or for other sectors where innovation is not formalized.

\section{Proposed Model - A Two-Dimensional Dynamic Classification}

A better and more rigorous growth-oriented classification construct can be achieved by applying methods of triangulation, as promoted by Denzin (1978), Jick (1979) and others (Johnson et al., 2007). Denzin (1978: 291), who is considered to be the first to outline how to triangulate methods, defined triangulation as 'the combination of methodologies in the study of the same phenomenon'. The use of triangulation allows researchers to be more confident of their results as well as develop more than one theoretical scheme for gathering and interpreting data from different sources, thereby increasing the validity of a study (Arksey \& Knight, 1999; Denzin, 1978; Jick, 1979). The rationale for applying triangulation for a construct such as the growth-oriented classification of SMEs is that the weaknesses of one method are offset by the strengths of others and vice versa (Lloyd, 2011).

A combined measure of growth classification of small businesses can be constructed using both past and forward-looking data, which is constructed from change in size information based on past data, together with forward looking indicator such as level of innovation. The resulting combined growth measure, which is based on triangulation of data from several indicators, yields a high level of reliability (Delmar, 1997). Additionally, the use of multiple growth indicators has been advocated as this can better capture heterogeneity in firm growth (Delmar et al., 2003). Moreover, the strength of such a dynamic classification of small businesses stems from the use of both factual 
size data from the past coupled with indicators that have been shown to be good predictors of future growth. One dimension is tangible in that it is based on factual size data of the business during previous years, providing a growth index through calculated change in size. This could be the weighed change in number of employees and sales over the last two years, serving as past looking index. A second dimension, which is a forward-looking index, is based on level of innovation of the business which can be measured by input or output indicators.

A typology of the two-dimension dynamic classification has the past growth on one axis and innovation of the small business on the other, as illustrated in Figure 2. Each of these dimensions is divided in two parts - a low and a high level. This forms a four quadrant typology labeled: Stagnant, Market Expansion, Product Variant, and Innovative High-Growth. The numerical boundaries for low and high levels of each axis have to be defined by the user, taking into consideration the relative size of the groups of firms that will be filtered out, as well as the error level. For example, accommodating for firms with negative growth rate in previous period, however having high innovation and growth potential; the low boundary of low growth rate can be set to negative value.

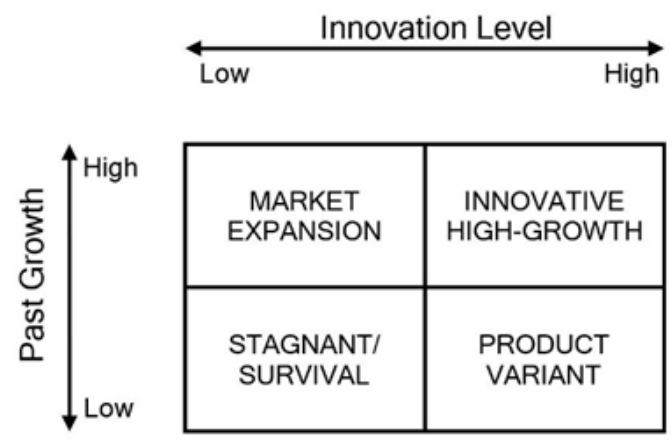

Figure 2. Dynamic classification typology - past growth and innovation

The quadrant formed by a high level in both axes - Innovative High-Growth - represents a business that has experienced high growth during the last two years, and has built its operations upon a high level of innovation, both of which together serve as a good predictor of continuing growth. Although high growth can occur in a variety of ways (Delmar et al., 2003), many such instances are technology-based entrepreneurships that utilize breakthrough innovation for high value creation that sustains competitive advantage and growth (Onetti et al., 2012).

On the other end of the scale, the quadrant formed by a low level on both axes - Stagnant - represents a business that did not show growth during the last two years, and is not utilizing any form of innovation. This business is operating in a survival mode as it is not likely to grow without innovation, based on its past performance. Owners of such small businesses may have been pushed into operating a business because of lifestyle or because of their inability to find employment (Fadahunsi, 2012), or they simply may have no desire to grow their business (Kalleberg \& Leicht, 1991).

The quadrant that combines high growth with low innovation refers to Market Expansion, where businesses grow in market coverage without introducing new products or services. Market expansion can be achieved by opening additional geographic sites (Barringer \& Greening, 1998), franchising (Barringer \& Greening, 1998), mergers and acquisitions (Hitt et al., 1990), and internationalization of a small business (Johanson \& Vahlne, 1990; Lu \& Beamish, 2006; Ruzzier et al., 2006). Market expansion through enlargement of the business would be a less effective growth route than through innovation, (Hitt et al., 1990).

Finally, the quadrant that combines low growth with high innovation - Product Variant -refers to businesses that base their operations on some form of innovation, either product, process or business model (Verhees \& Meulenberg 2004). However, these are firms that have not exhibited growth in the past. This fact has several interpretations, ranging from a newly established business with no past data regarding growth, or an on-going business that has not exhibited growth in the past because of any number of shortcomings.

\section{Discussion}

With the understanding that only few, out of the totality of all small business, are responsible for the greatest contribution to growth and job creation, and given the scarcity of financial resources for incentive programs; 
policymakers should be interested in those firms that are likely to grow (Dennis, 2011; Morrison et al., 2003; Stenholm, 2011). This holds true particularly at times of social and economic crisis. The COVID-19 pandemic crisis provided an example of such situation, with the many jobs lost and the scarcity of financial resources due to investment in relief efforts and consequences of the pandemic.

The advantage of the proposed dynamic classification is that it considers both past growth indicators together with indicators of future growth. Past growth indicators can include number of employees and sales; while forward looking indicator is based on level of innovation. Moreover, level of innovation in itself can be constructed from two distinct indicators - measured at the firms' input - investment in research and development, and output - number of patents. Such triangulation between several indicators results in robust measure of growth potential. Thus, dynamic classification can serve as a tool for the identification of pro-growth small businesses and would be much more effective and reliable than size-based classification or simply addressing specific groups, such as high-tech entrepreneurships (Dennis, 2011).

Similarly, dynamic classification can serve as an effective tool for research. The academic research in the field of small and medium-sized enterprises is vast and growing due to the importance of the field to the economy and its growth (Hisrich \& Drnovsek, 2002; Morrison et al., 2003). Current research investigates a myriad of issues and concepts regarding small firms including strategy, marketing, finance, management theories, performance measurement, research and development, internationalization, electronic commerce, social responsibility, and more (Astrachan, 2010; Columba et al., 2010; Matlay, 2004; Murillo \& Lozano, 2006; Pett \& Wolff, 2011; Ruzzier et al., 2006). While engaging in this work, researchers are putting great effort into achieving cost effective data collection and quality, into coping with low response rate, and into finding useful data (Dennis, 2003; Newby et al., 2003). Thus, improved targeting of business samples for research purposes, such as targeting of a single cell from the quadrants of Figure 2, can serve to increase the cost effectiveness and relevance of data collection.

\section{Conclusion}

The proposed dynamic construct for SME classification is composed of past data together with indicators that has been shown to be correlated with future growth, and thus may serve as a reliable measure of a trend over time that includes growth.

However, some limitations should be noted. First, the proposed model for dynamic classification of SMEs is based on theoretical review of the literature, and thus lacks empirical support. Second, although the proposed model uses growth evaluation which is based on the triangulation of past data together with forward looking indicators; it does not consider possible variation stemming from different business sectors and industries.

Possible future research should test the proposed dynamic classification by applying it to a set of firms. Such application would further substantiate the validity and usefulness of this classification. Additionally, more research is needed to identify the optimal construct of such a dynamic classification especially which indicators best contribute to a highly accurate prediction of trends in growth, as well as validating it through empirical testing.

The proposed dynamic classification provides identification of a central attribute of small businesses- the growth potential of the firm based on evidence from the past together with forward looking indicators. As such, dynamic classification differs fundamentally from size-based classification in that it provides unique information about changes over time; serving important needs within the public policy domain as well as academic research. The dynamic classification does not come to replace the common size-based classification which is essential in itself to determine who are the small firms, as well as serving for other administrative needs.

\section{References}

Acs, Z. J., \& Mueller, P. (2008). Employment effects of business dynamics: Mice, gazelles and elephants. Small Business Economics, 30(1), 85-100. https://doi.org/10.1007/s11187-007-9052-3

Aghion, P., \& Howitt, P. (1992). A model of growth through creative destruction. Econometrica, 60, 323-351. https://doi.org/10.2307/2951599

Ahlstrom, D. (2010). Innovation and growth: how business contributes to society. The Academy of Management Perspectives, 24(3), 11-24. https://doi.org/10.5465/amp.24.3.11

Arksey, H., \& Knight, P. (1999). Interviewing for social scientists: an introductory resource with examples. London: Sage. https://doi.org/10.4135/9781849209335

Asa, A. R., \& Prasad, N. S. (2014). Analysis on the factors that determine sustainable growth of small firms in Namibia. International Journal of Management Science and Business Administration, 1(1), 5-11. 
https://doi.org/10.18775/ijmsba.1849-5664-5419.2014.11.1001

Astrachan, J. H. (2010). Strategy in family business: Toward a multidimensional research agenda. Journal of Family Business Strategy, 1(1), 6-14. https://doi.org/10.1016/j.jfbs.2010.02.001

Ayyagari, M., Beck, T., \& Demirguc-Kunt, A. (2007). Small and medium enterprises across the globe. Small Business Economics, 29, 415-434. https://doi.org/10.1007/s11187-006-9002-5

Baker, H. K., Kumar, S., \& Pandey, N. (2021). Thirty years of small business economics: a bibliometric overview. Small Business Economics, 56(1), 487-517. https://doi.org/10.1007/s11187-020-00342-y

Bannier, C. E., \& Zahn, S. (2014). SMEs' growth heterogeneity-evidence from regional developments. International Journal of Business Administration, 5(2), 23. https://doi.org/10.5430/ijba.v5n2p23

Barbero, J. L., Casillas, J. C., \& Feldman, H. D. (2011). Managerial capabilities and paths to growth as determinants of high-growth small and medium-sized enterprises. International Small Business Journal, 29(6), 671-694. https://doi.org/10.1177/0266242610378287

Barringer, B. R., \& Greening, D. W. (1998). Small business growth through geographic expansion: a comparative case study. Journal of Business Venturing, 13(6), 467-492. https://doi.org/10.1016/S0883-9026(97)00038-4

Berisha, G., \& Pula, J. S. (2015). Defining small and medium enterprises: a critical review. Academic Journal of Business, Administration, Law and Social Sciences, 1(1), 17-28.

Birch, D. (1987). Job generation in America. New York: The Free Press.

Birch, D., Haggerty, A., \& Parsons, W. (1994). Gazelle jobs. Corporate almanac.

Birch, D., Haggerty, A., \& Parsons, W. (1997). Who's Creating Jobs?. Cambridge, MA: Cognetics.

Boston, D. T. (2011). The gazelle index. In The federal reserve and the kauffman foundation conference on small business and entrepreneurship during an economic recovery, 9-10 November 2011.

Bridge, S., O’Neill, K., \& Cromie, S. (1998). Understanding enterprise, entrepreneurship, and small business. London: MacMillan Business. https://doi.org/10.1007/978-1-349-26171-0

Buckley, P. J., \& Mirza, H. (1997). Introduction. In P. J. Buckley, J. Campos, H. Mirza, \& E. White (Eds.), International technology transfer by small and medium-sized enterprises: country studies (pp. 1-5). London: Macmillan. https://doi.org/10.1007/978-1-349-25686-0_1

Burns, P., \& Dewhurst, J. (1996). Small business and entrepreneurship. London: MacMillan Business. https://doi.org/10.1007/978-1-349-24911-4

Chege, S. M., \& Wang, D. (2020). Information technology innovation and its impact on job creation by SMEs in developing countries: an analysis of the literature review. Technology Analysis \& Strategic Management, 32(3), 256-271. https://doi.org/10.1080/09537325.2019.1651263

Christensen, C. M. (1997). The innovator's dilemma: When new technologies cause great firms to fail. Boston: Harvard Business School Press.

Christensen, C. M., \& Raynor, M. (2003). The innovator's solution. Boston: Harvard Business School Press.

Christensen, C. M., McDonald, R., Altman, E. J., \& Palmer, J. E. (2018). Disruptive innovation: An intellectual history and directions for future research. Journal of Management Studies, 55(7), 1043-1078. https://doi.org/10.1111/joms.12349

Coad, A. (2007). A closer look at serial growth rate correlation. Review of Industrial Organization, 31(1), 69-82. https://doi.org/10.1007/s11151-007-9135-y

Coad, A. (2009). The growth of firms: A survey of theories and empirical evidence. Cheltenham: Edward Elgar Publishing. https://doi.org/10.4337/9781848449107

Coad, A., \& Rao, R. (2008). Innovation and firm growth in high-tech sectors: A quantile regression approach. Research Policy, 37(4), 633-648. https://doi.org/10.1016/j.respol.2008.01.003

Coad, A., Daunfeldt, S. O., \& Halvarsson, D. (2018). Bursting into life: firm growth and growth persistence by age. Small Business Economics, 50(1), 55-75. https://doi.org/10.1007/s11187-017-9872-8

Coad, A., Daunfeldt, S. O., Holzl, W., Johansson, D., \& Nightingale, P. (2014). High-growth firms: introduction to the special section. Industrial and Corporate Change, 23(1), 91-112. https://doi.org/10.1093/icc/dtt052 
Coe, D. T., \& Helpman, E. (1995). International R\&D spillovers. European Economic Review, 39(5), 859-887.

Columba, F., Gambacorta, L., \& Mistrulli, P. E. (2010). Mutual Guarantee institutions and small business finance. Journal of Financial Stability, 6(1), 45-54. https://doi.org/10.1016/0014-2921(94)00100-E

Congressional Research Service. (2020). Small business size standards: a historical analysis of contemporary issues. Retrieved February 15, 2021, from https://fas.org/sgp/crs/misc/R40860.pdf

Daunfeldt, S. O., \& Halvarsson, D. (2015). Are high-growth firms one-hit wonders? Evidence from Sweden. Small Business Economics, 44(2), 361-383. https://doi.org/10.1007/s11187-014-9599-8

Davis, S. J., Haltiwanger, J., \& Schuh, S. (1996). Small business and job creation: Dissecting the myth and reassessing the facts. Small Business Economics, 8(4), 297-315. https://doi.org/10.1007/BF00393278

Delmar, F. (1997). Measuring growth: methodological considerations and empirical results. In R. Donckels, \& A. Miettinen (Eds.), Entrepreneurship and SME research: On its way to the next millennium (pp. 199-216). Hants, England: Ashgate.

Delmar, F., Davidsson, P., \& Gartner, W. B. (2003). Arriving at the high-growth firm. Journal of Business Venturing, 18(2), 189-216. https://doi.org/10.1016/S0883-9026(02)00080-0

Demir, R., Wennberg, K., \& McKelvie, A. (2017). The strategic management of high-growth firms: A review and theoretical conceptualization. Long Range Planning, 50(4), 431-456. https://doi.org/10.1016/j.lrp.2016.09.004

Dennis, Jr. W. J. (2011). Entrepreneurship, small business and public policy levers. Journal of Small Business Management, 49(1), 92-106. https://doi.org/10.1111/j.1540-627X.2010.00316.x

Dennis, W. J. (2003). Raising response rates in mail survey of small business owners: results of an experiment. Journal of Small Business Management, 41(3), 278-295. https://doi.org/10.1111/1540-627X.00082

Denzin, N. K. (1978). The research act: A theoretical introduction to sociological methods. New York: McGraw-Hill.

Engelbrecht, H. J. (1997). International R\&D Spillovers amongst OECD Economies. Applied Economics Letters, 4, 315-319. https://doi.org/10.1080/758532600

European Commission. (2020). User Guide to the SME Definition. Retrieved February 15, 2021, from https://ec.europa.eu/docsroom/documents/42921

Fadahunsi, A. (2012). The growth of small businesses: towards a research agenda. American Journal of Economics and Business Administration, 4(1), 105-115. https://doi.org/10.3844/ajebasp.2012.105.115

Foster, R., \& Kaplan, S. (2001). Creative destruction: Why companies that are built to last underperform the market - and how to successfully transform them. New York: Currency Books.

Freel, M. S., \& Robson, P. J. (2004). Small firm innovation, growth and performance evidence from Scotland and Northern England. International Small Business Journal, 22(6), 561-575. https://doi.org/10.1177/0266242604047410

Fritsch, M., \& Wyrwich, M. (2017). The effect of entrepreneurship on economic development - an empirical analysis using regional entrepreneurship culture. Journal of Economic Geography, 17(1), 157-189. https://doi.org/10.1093/jeg/lbv049

Gamidullaeva, L. A., Vasin, S. M., \& Wise, N. (2020). Increasing small-and medium-enterprise contribution to local and regional economic growth by assessing the institutional environment. Journal of Small Business and Enterprise Development. https://doi.org/10.1108/JSBED-07-2019-0219

Glancey, K. (1998). Determinants of growth and profitability in small entrepreneurial firms. International Journal of Entrepreneurial Behaviour \& Research, 4(1), 18-27. https://doi.org/10.1108/13552559810203948

Grossman, G. M., \& Helpman, E. (1991). Innovation and growth in the global economy. Cambridge, MA: MIT Press.

Hansen, B., \& Hamilton, R. T. (2011). Factors distinguishing small firm growers and non-growers. International Small Business Journal, 29(3), 278-294. https://doi.org/10.1177/0266242610381846

Helpman, E. (2010). The mystery of economic growth. Cambridge MA: Belknap Press. https://doi.org/10.2307/j.ctv1c5cx4v

Henrekson, M., \& Johansson, D. (2010). Gazelles as job creators: A survey and interpretation of the evidence. Small 
Business Economics, 35(2), 227-244. https://doi.org/10.1007/s11187-009-9172-z

Hisrich, R. D., \& Drnovsek, M. (2002). Entrepreneurship and small business research-a European perspective. Journal of Small Business and Enterprise Development, 9(2), 172-222. https://doi.org/10.1108/14626000210427348

Hitt, M. A., Hoskisson, R. E., \& Ireland, R. D. (1990). Mergers and acquisitions and managerial commitment to innovation in M-form firms. Strategic Management Journal, 11(4), 29-48.

Holmes, S., \& Gibson, B. (2001). Definition of small business - final report. The University of Newcastle.

Iansiti, M. (1995). Technology integration: Managing technological evolution in a complex environment. Research Policy, 24(4), 521-542. https://doi.org/10.1016/S0048-7333(94)00781-0

Jick, T. D. (1979). Mixing qualitative and quantitative methods: Triangulation in action. Administrative Science Quarterly, 24, 602-611. https://doi.org/10.2307/2392366

Johanson, J., \& Vahlne, J. E. (1990). The Mechanism of Internationalization. International Marketing Review, 7(4), 11-24. https://doi.org/10.1108/02651339010137414

Johnson, R. B., Onwuegbuzie, A. J., \& Turner, L. A. (2007). Toward a definition of mixed methods research. Journal of Mixed Methods Research, 1(2), 112-133. https://doi.org/10.1177/1558689806298224

Kalleberg, A. L., \& Leicht, K. T. (1991). Gender and organizational performance: Determinants of small business survival and success. Academy of Management Journal, 34(1), 136-161. https://doi.org/10.2307/256305

Kersten, R., Harms, J., Liket, K., \& Maas, K. (2017). Small firms, large impact? A systematic review of the SME finance literature. World Development, 97, 330-348. https://doi.org/10.1016/j.worlddev.2017.04.012

Kirchhoff, B. A. (1994). Entrepreneurship and dynamic capitalism. Westport, CT: Praeger.

Koryak, O., Mole, K. F., Lockett, A., Hayton, J. C., Ucbasaran, D., \& Hodgkinson, G. P. (2015). Entrepreneurial leadership, capabilities and firm growth. International Small Business Journal, 33(1), 89-105. https://doi.org/10.1177/0266242614558315

Lambert, T. E. (2018). Does innovation chase profits, or do profits chase innovation?. Journal of Applied Management and Investments, 7(3), 141-146.

Landes, D., Mokyr, J., \& Baumol, W. (2010). The invention of enterprise: Entrepreneurship from ancient Mesopotamia to modern times. Princeton, NJ: Princeton University Press. https://doi.org/10.1515/9781400833580

Li, Y., \& Rama, M. (2015). Firm dynamics, productivity growth, and job creation in developing countries: The role of micro-and small enterprises. The World Bank Research Observer, 30(1), 3-38. https://doi.org/10.1093/wbro/lkv002

Lian, Y., Foley, M., Liu, X., \& Lu, J. (2011). The role of R\&D in improving firm growth: evidence from high tech companies in China. International Journal of Business and Economics Perspectives, 6(1), 108-125.

Lloyd, S. (2011). Triangulation research to inform corporate reputation theory and practice. Corporate Reputation Review, 14(3), 221-233. https://doi.org/10.1057/crr.2011.16

Lu, J. W., \& Beamish, P. W. (2006). SME internationalization and performance: Growth vs. profitability. Journal of International Entrepreneurship, 4(1), 27-48. https://doi.org/10.1007/s10843-006-8000-7

Lukács, E. (2005). The economic role of SMEs in world economy, especially in Europe. European Integration Studies, 4(1), 3-12.

Mason, C., \& Brown, R. (2013). Creating good public policy to support high-growth firms. Small Business Economics, 40(2), 211-225. https://doi.org/10.1007/s11187-011-9369-9

Mason, G., Bishop, K., \& Robinson, C. (2009). Business growth and innovation: The wider impact of rapidly growing firms in UK city-regions. London: NESTA.

Matlay, H. (2004). E-entrepreneurship and small e-business development: towards a comparative research agenda. Journal of Small Business and Enterprise Development, 11(3), 408-414. https://doi.org/10.1108/14626000410551663

Meredith, G. G. (1992). Small business management in Australia. Sydney: McGraw-Hill. 
Morais, G. M., Dos Santos, V. F., Da Silva Tolentino, R. D. S., \& Cordeiro, H. (2021). Intrapreneurship, innovation, and competitiveness in organization. International Journal of Business Administration, 12(2). https://doi.org/10.5430/ijba.v12n2p1

Morrison, A., Breen, J., \& Ali, S. (2003). Small business growth: intention, ability, and opportunity. Journal of Small Business Management, 41(4), 417-425. https://doi.org/10.1111/1540-627X.00092

Murillo, D., \& Lozano, J. M. (2006). SMEs and CSR: An approach to CSR in their own words. Journal of Business Ethics, 67(3), 227-240. https://doi.org/10.1007/s10551-006-9181-7

Murphy, J. (1996). Small business management. London: Pitman.

Nakku, V. B., Agbola, F. W., Miles, M. P., \& Mahmood, A. (2020). The interrelationship between SME government support programs, entrepreneurial orientation, and performance: A developing economy perspective. Journal of Small Business Management, 58(1), 2-31. https://doi.org/10.1080/00472778.2019.1659671

Newby, R., Watson, J., \& Woodliff, D. (2003). SME survey methodology: Response rates, data quality, and cost effectiveness. Entrepreneurship Theory and Practice, 28(2), 163-172. https://doi.org/10.1046/j.1540-6520.2003.00037.x

Nooteboom, B. (1988). The facts about small business and the real values of its 'Life World'. American Journal of Economics and Sociology, 47(3), 299-314. https://doi.org/10.1111/j.1536-7150.1988.tb02043.x

Onetti, A., Zucchella, A., Jones, M. V., \& McDougall-Covinm, P. P. (2012). Internationalization, innovation and entrepreneurship: business models for new technology-based firms. Journal of Management \& Governance, 16(3), 337-368. https://doi.org/10.1007/s10997-010-9154-1

Parker, S., Storey, D., \& Van Witteloostuijn, A. (2010). What happens to gazelles? The importance of dynamic management strategy. Small Business Economics, 35, 203-226. https://doi.org/10.1007/s11187-009-9250-2

Peter, F., Adegbuyi, O., Olokundun, M., Peter, A. O., Amaihian, A. B., \& Ibidunni, A. S. (2018). Government financial support and financial performance of SMEs. Academy of Strategic Management Journal, 17.

Pett, T. L., \& Wolff, J. A. (2011). Examining SME performance: the role of innovation, R\&D and internationalization. International Journal of Entrepreneurial Venturing, 3(3), 301-314. https://doi.org/10.1504/IJEV.2011.041277

Qian, G., \& Li, L. (2003). Profitability of small-and medium-sized enterprises in high-tech industries: the case of the biotechnology industry. Strategic Management Journal, 24(9), 881-887. https://doi.org/10.1002/smj.344

Romano, C. A. (1990). Identifying factors which influence product innovation: a case study approach. Journal of Management Studies, 27(1), 75-95. https://doi.org/10.1111/j.1467-6486.1990.tb00754.x

Ruzzier, M., Hisrich, R. D., \& Antoncic, B. (2006). SME internationalization research: past, present, and future. Journal of Small Business and Enterprise Development, 13(4), 476-497. https://doi.org/10.1108/14626000610705705

Schumpeter, J. A. (1911). The theory of economic development (transl. 1934). Cambridge, Mass: Harvard University Press.

Schumpeter, J. A. (1942). Capitalism, socialism and democracy. New York: Harper and Row.

Schwartz, D., \& Malach-Pines, A. (2007). High technology entrepreneurs versus small business owners in Israel. Journal of Entrepreneurship, 16(1), 1-17. https://doi.org/10.1177/097135570601600101

Sen, S. (2011). Corporate social responsibility in small and medium enterprises: application of stakeholder theory and social capital theory. DBA thesis, Southern Cross University, Lismore, NSW.

Shane, S. A. (2008). The illusions of entrepreneurship: The costly myths that entrepreneurs, investors, and policy makers live by. New Haven, CT: Yale University Press.

Shane, S. A. (2009). Why encouraging more people to become entrepreneurs is bad public policy. Small Business Economics, 33(2), 141-149. https://doi.org/10.1007/s11187-009-9215-5

Shirmohammadi, Y., Nikmanesh, S., \& Hasannejad, F. (2020). The impact of product innovation and marketing on product internationalization in start-ups. International Journal of Business and Economics Perspectives, 3(2), $81-101$.

Singh, A., \& Whittington, G. (1968). Growth, profitability and valuation. In Department of applied economics, university of cambridge, Occasional Paper, No 7. Cambridge: Cambridge University Press. 
Small Business Administration-SBA. (2019). Small business size standards. Retrieved February 15, 2021, from https://www.sba.gov/document/support--table-size-standards

Small Business Administration-SBA. (2020). United states small business profile, 2020. Retrieved from https://cdn.advocacy.sba.gov/wp-content/uploads/2020/06/04144224/2020-Small-Business-Economic-Profile-U S.pdf

Stanworth, M. J. K., \& Curran, J. (1976). Growth and the small firm - an alternative view. Journal of Management Studies, 13(2), 95-110. https://doi.org/10.1111/j.1467-6486.1976.tb00527.x

Stenholm, P. (2011). Innovative behavior as a moderator of growth intentions. Journal of Small Business Management, 49(2), 233-251. https://doi.org/10.1111/j.1540-627X.2011.00323.x

Storey, D. J. (2016). Understanding the small business sector. London, UK: Routledge. https://doi.org/10.4324/9781315544335

Than, S. T., Nguyen, C. H., Tran, T. Q., \& Le, P. B. (2019). Building competitive advantage for Vietnamese firms: The roles of knowledge sharing and innovation. International Journal of Business Administration, 10(4), 1-12. https://doi.org/10.5430/ijba.v10n4p1

Thurik, R., \& Wennekers, S. (2004). Entrepreneurship, small business and economic growth. Journal of Small Business and Enterprise Development, 11(1), 140-149. https://doi.org/10.1108/14626000410519173

Verhees, F. J., \& Meulenberg, M. T. (2004). Market orientation, innovativeness, product innovation, and performance in small firms. Journal of Small Business Management, 42(2), 134-154. https://doi.org/10.1111/j.1540-627X.2004.00102.x

Wagner, J. (1992). Firm size, firm growth, and the persistence of chance: Testing Gibrat's Law with establishment data for Lower Saxony. Small Business Economics, 4, 125-132. https://doi.org/10.1007/BF00389853

Westhead, P., \& Cowling, M. (1995). Employment change in independent owner-managed high-technology firms in Great Britain. Small Business Economics, 7, 111-140. https://doi.org/10.1007/BF01108686

Wiklund, J., Patzelt, H., \& Shepherd, D. (2009). Building an integrative model of small business growth. Small Business Economics, 32(4), 351-374. https://doi.org/10.1007/s11187-007-9084-8

Wolff, J. A., \& Pett, T. L. (2006). Small firm performance: modeling the role of product and process improvements. Journal of Small Business Management, 44(2), 268-284. https://doi.org/10.1111/j.1540-627X.2006.00167.x

Wong, P. K., Ho, Y. P., \& Autio, E. (2005). Entrepreneurship, innovation and economic growth: Evidence from GEM data. Small Business Economics, 24(3), 335-350. https://doi.org/10.1007/s11187-005-2000-1

Zahra, S. A., \& Nielsen, A. P. (2002). Sources of capabilities, integration and technology commercialization. Strategic Management Journal, 23(5), 377-398. https://doi.org/10.1002/smj.229

\section{Copyrights}

Copyright for this article is retained by the author(s), with first publication rights granted to the journal.

This is an open-access article distributed under the terms and conditions of the Creative Commons Attribution license (http://creativecommons.org/licenses/by/4.0/). 